\title{
Discretion and Decentralization: Framing Government Policy in Regional Innovation Policies
}

\author{
Deasy Mauliana* Abdul Razak Marthen Arie Farida Patittingi \\ Faculty of Law, Hasanuddin University, South Sulawesi, Indonesia
}

\begin{abstract}
Discretion under normal circumstances it would be very useful in a wide range of government activity to fill the void the policy. Also, regulations give freedom to State officials to be able to act on their own initiative. However, as it turns out into practice, such legal issues are clearly very dangerous for local governments implementing innovative policies for regional progress. This research focuses on the analysis study of a discretion authority of regional government in making local government innovation policies. The research is a normative-legal research using a statute, case, and conceptual approaches; it is a reform-oriented research. The results show that the essence of discretionary power is free-power that no longer exercised by following the consideration of rules and regulations. Discretionary power holders in acting do not need to underlie the law strictly because it is an exception then discretionary power can only be used casually or contextually. Discretion reflects the idea of the constitutional State, then the action of discretion by State officials in the framework of innovative policy efforts is actually a moral manifestation of State' responsibility. An ideal model of discretionary policy for innovation programs in local government can be said as a description of the basic system of implementing discretion for policies that are innovative, where the legal actions taken by local governments are based on an ideal principle. This model is not structural or hierarchical in nature, but a unified whole with each basic element having the same strengths and interests, so that all elements are bound together with strengths and positions, both from elements of the constitutional values and integrated collaboration.
\end{abstract}

Keywords: Discretion; Decentralization; Innovation; Local Government; Legal Policy

DOI: $10.7176 / \mathrm{JLPG} / 97-05$

Publication date:May $31^{\text {st }} 2020$

\section{Introduction}

Indonesia is a constitutional State. ${ }^{1}$ Law-based government will give the guarantee of people's basic rights protection so that the interest sides for the government that exercising State power and peoples as subjects of the State' proprietor can always be in accordance or in line. ${ }^{2}$ Therefore, the submission of the concept of the constitutional State as one of the legal foundations of governance plays a very important role not only as a corridor for government actions but also serves as a basic reference and benchmark for evaluating governance. ${ }^{3}$

As the conception of the constitutional State and the welfare State, the government is obliged to provide public service which in which the government does not only implement the laws and regulations, but also the government has the right to create concrete legal rules in order to realize the objectives of the laws and regulations. One manifestation of the constitutional State is a bureaucracy to run the wheels of government. In running these duties, the government is equipped with various authorities both attributive and delegative.

According to Abdul Razak, ${ }^{4}$ said that as the main duty of the government is to provide public service, emerge the principle "the government must not refuse to provide public services on the grounds that there are no laws and regulations that govern it". But conversely, the government must find and provide a solution by finding the law itself.

As the development of the community, certain situations are often found that require the government to take policy quickly, because an urgency so that the government cannot use its authority, especially the binding authority in taking legal and factual actions normally. The decision or action taken by the government is known as discretion. The term discretion or freies ermessen or the principle of discretion in administrative law implies a broad obligation and powers, that is an action to be taken and the freedom to choose act or not.

Although, policies as issued by State administration officials as state administrators in its implementation have the potential to cause legal and administrative problems. On the pretext of a policy that is destined for the benefit, sometimes the policy beyond the authority set by the law. For this reason, public control is needed over a series of actions by government officials or State administrative equipment in running clean and authoritative

\footnotetext{
${ }^{1}$ Aspan, Z., \& Yunus, A. (2019). The right to a good and healthy environment: Revitalizing green constitution. IOP Conference Series: Earth and Environmental Science, 343 (1): 012067.

${ }^{2}$ Vega, A., Chiasson, M., \& Brown, D. (2013). Understanding the Causes of Informal and Formal Discretion in the Delivery of Enterprise Policies: A Multiple Case Study. Environment and Planning C: Government and Policy, 31(1), 102-118. https://doi.org/10.1068/c1101b

${ }^{3}$ Ilmar, A. (2014). Hukum Tata Pemerintahan. Prenadamedia. Jakarta. p. 37

${ }^{4}$ Razak, A. (2005). Kedudukan dan Fungsi Peraturan Kebijakan di Bidang Perizinan dalam Rangka Penyelenggaraan Pemerintahan. (Dissertation). Post-graduate, Hasanuddin University, p.5
} 
government in order to realize good governance. ${ }^{1}$

Discretion is needed as a complement of the principle of legality, as the principle of law which states that every act or State administration action must be based on statutory provisions. ${ }^{2}$ This discretion is used because of; the first, an emergency condition that makes it impossible to apply written provisions; the second, there are no regulations governing it; the third, there are regulations but the content is vague or multiple-interpretations. Freedom of discretion is freedom of administration which includes freedom of administration (interpretatieverijheid), freedom of consideration (beoorelingsvrijheid), and freedom to take policy (beleidsvrijheid). ${ }^{3}$

Among the general principles of good governance, the most basic is the prohibition of abuse of authority and actions arbitrarily. However, regulations also give freedom to State officials to be able to act on their own initiative, especially in solving problems that require immediate handling but regulations for solving those problems do not yet exist.

Actually, in several regions, an innovation policy by the local government is very vulnerable to legal problems such as Sragen regent who is caught in a criminal act of Regional Budget corruption in Sragen regency because he has created an innovation with One Stop Service (OSS) program which has been sentenced to 7 years. ${ }^{4}$ As well Jembrana regent, I Gusti Winasa who tried an innovation policy by creating a streamlined and efficient regional apparatus structure so as to be able to utilize the small amount of the Regional Budget for free services in health and education, but finally he was caught in a corruption case of factory construction procurement and was sentenced to for 7 years. ${ }^{5}$ Likewise, with the former Governor of DKI Jakarta, Basuki Tjahaja Purnama, who issued a policy by asking developers to add contributions as a condition for continuing the reclamation project which is used for welfare programs, such as for the provision of flats for poor people. In addition, the application of ebudgeting is used in preparing the regional budget of DKI Jakarta that is not based on legal basis. ${ }^{6}$

Such legal issues are clearly very dangerous for local governments implementing innovative policies for regional progress. If innovation is a violation of rules, then innovation should not be encouraged or appreciated, let alone made as a policy. If innovation is against the law, then innovation must be severely punished, if necessary it must be eliminated from any dictionary that humans have. In turn, misunderstandings like this also result in rejection, reluctance, and fear of innovation by local governments. In fact, it is very possible that what actually happened was reluctant or unable to innovate, so that there was a violation of the law. Regional heads with good intentions, strong and trusted leadership and have various breakthroughs in the form of innovation and renewal will hesitate to realize their innovations due to unclear legal basis.

Based on the legal construction and issues, the main issue of this paper will be to review the local government innovation policies set out in the Act that have been able to be an optimal means of improving public services to local governments and how its relevance to discretion in making innovation policies so that it can effectively realize good governance.

\section{Method of the Research}

This study is a normative-legal research by using statute, case, and conceptual approaches. ${ }^{7}$ Data were analyzed with descriptive qualitative analysis with content analysis. In this study, the authors used the qualitative research method, which (in general) generates words rather than numbers as data for analysis. ${ }^{8}$ This research focuses on the analysis study of a discretion authority of regional government in making local government innovation policies.

\section{Discretion in Making Regional Innovation Policies: Between Ideality and Reality}

Discretion as a concept in government often indicates a dilemma in its realization. A dilemma of discretion conduct by State or government officials occurs because of the innate nature of the conduct, namely freedom. At the level of abstraction, freedom is not problematic because it is in the speculative idealization of ideas and/or understandings that contain philosophical meaning. It is only when the freedom of discretionary action enters the

\footnotetext{
${ }^{1}$ Aristoni, (2014), Tindakan Hukum Diskresi Dalam Konsep Walfare State Perspektif Hukum Administrasi Negara dan Hukum Islam, Jurnal Penelitian STAIN Kudus, 8 (2): 224

${ }^{2}$ Ansori, L. (2015). Diskresi dan Pertanggungjawaban Pemerintah Dalam Penyelenggaraan Pemerintahan. Journal of Juridical 2 (1): 137

3 Hadjon, P.M. Discretionary Power dan Asas-Asas Umum Pemerintahan Yang Baik. Paper on the National Seminar "Aspek Pertanggungjawaban Pidana Dalam Kebijakan Publik dari Tindak Pidana Korupsi”, Semarang, 6-7 May 2004, p. 6; See also Hadjon, P. M. (2011). Introduction to the Indonesian administrative law. Yogyakarta: Gadjah Mada University Press, p. 12-13

${ }^{4}$ Merdeka.com Available online at: https://www.merdeka.com/peristiwa/ma-vonis-mantan-bupati-sragen-7- tahun-penjara.html accessed on 1 November 2019

${ }^{5}$ BeritaSatu.com. Available online at: https://www.beritasatu.com/nasional/133220/ma-vonis-mantan-bupati- jembrana accessed on 1 November 2019

${ }^{6}$ Kompasiana.com. Available online at: http://www.kompasiana.com/hendra_budiman/landasan-hukum-inovasi- kota-cerdas accessed on 1 November 2019

${ }^{7}$ Marzuki, P.M. (2010). Penelitian Hukum. Jakarta: Kencana Prenada Media Group., p. 93

${ }^{8}$ Patton, M.Q., and Cochran, M. (2007). A Guide to Using Qualitative Research Methodology, Medecins Sans Frontieres, UK.
} 
pragmatic or concrete area, it enabling a dilemma. Between the normative-juridical truth and a freedom from the subjective, absolute nature of the officials concerned. Although a freedom of conduct is for the welfare of the people, and therefore in this reform era it is expected that truly authority in terms of freedom of conduct (discretionary) is used for the peoples. ${ }^{1}$

In general, the nature of dilemma of the value of freedom of power that exists in discretionary is sourced in theoretical views on legality in government actions and freedom as an infinite abstraction of conduct. So that the impression appears that the conducts of the government is outside the principles of legality. The freedom of conduct of the government (discretion) is clearly incompatible with such a mindset (legality), because the mindset of discretion is a mindset that adjusts to the reality of the life process with the principles and broader legal politics, because the law is for the community not community for law. ${ }^{2}$

This concept of discretion should be seen as an integral part of the implementation of the law-based State system. So that the discretion can still be interpreted as part of legal action by a State or government official because the freedom used is not in the framework of personal interests but remains within the framework of the essence of the interests of the citizens as a whole and as a reflection of State responsibility.

Wilson ${ }^{3}$ said that government reform is essentially an effort to make fundamental reforms and changes to the system of governance, especially concerning institutional aspects (organization), management (business processes) and human resources of apparatus. Government reforms (especially public services) in various regions in Indonesia are relatively diverse in their forms. The reforms include creating programs and policies designed by the local government by considering economic facilities, technical capabilities and administrative facilities for implementing organs which must also consider the ethical feasibility that exists and develops in their communities.

The dynamics of development in the regions is a picture of the progressiveness of the development efforts undertaken by the government in the regions. This progress is a manifestation of the power and ability of local governments to manage the potential of their respective regions. In this reform era, the ability of local governments is indeed triggered regulatively in order to have new skills that are able to build and develop an innovative product that can improve the welfare of the people in their area. Therefore, the local government has the power and capability in several aspects of development including aspects of institutional (organization), management (business process) and human resources of apparatus. In addition, the dimension of leadership is also a main key, especially to bring up progressive ideas that contain innovative nature, which can break the deadlock of development efforts that are planned and will be implemented, or are being implemented.

As a rational choice, innovation seems to have become an inseparable part of the demands of public organizations in both the central and local governments. This is in line with various changes and dynamics of community demands. Innovation is expected to be a strategy in increasing the leverage of organizational performance both in producing products and services. One of the strategic efforts of public organizations to be able to continue to make changes is to create new products (both in terms of goods and services), new structures, new relationships and cultures. ${ }^{4}$ Thus, there is a logical consequence for public organizations as public service entities, namely the application of the principle of service based on effective, efficient and productive indicators and no longer applying the principle of origin to conduct services.

Local government innovation policy refers to the principle of increasing efficiency, effectiveness, service quality, there is no conflict of interests, oriented to the public interest, performed openly, meets the values of propriety, and the results cannot be accounted for their own sake. If compared diametrically, Wilson's theory of the nature of government reform as an effort to reform and fundamental changes to the system of governance, especially concerning institutional aspects (organization), management (business process) and human resources of apparatus, the basic principles of local government innovative policy can be seen on Figure 1.

\footnotetext{
${ }^{1}$ Fendri, A. (2015). Kebebasan bertindak pemerintah (diskresi)sebagai perwujudan nilai-nilai moral dan etika. The Journal of Law Science, 4 (3): 138 .

${ }^{2}$ Ibid

${ }^{3}$ Wilson, J., \& Stapleton, K. (2007). The discourse of resistance: Social change and policing in Northern Ireland. Language in Society, 36(3), 393-425. doi:10.1017/S0047404507070194.

${ }^{4}$ Sururi, A. (2017). Inovasi Kebijakan dalam Perspektif Administrasi Publik Menuju Terwujudnya Good Public Policy Governance, Jurnal Spirit Publik, 12 (2): 14-31.
} 

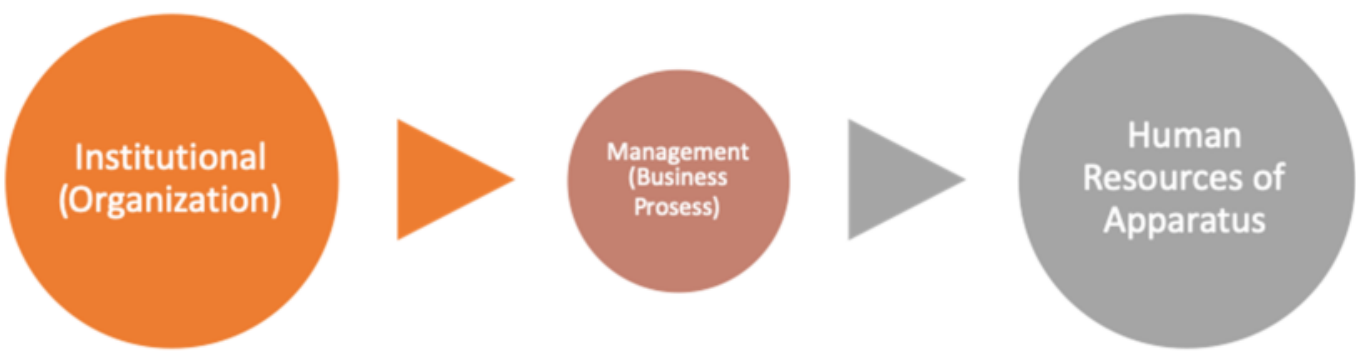

Figure 1. Main principles of local government innovation policy

In the dynamics of regional community development, generally known the theory of innovation-diffusion in an effort to advance regional life in a variety of contexts of innovative change. Theory of innovation-diffusion is always associated with the process of community development. Innovation is the beginning for social change, and social change is basically the core of community development. Rogers ${ }^{1}$ explained that the process of diffusion is part of the process of social change. Social change is a process in which changes occur in the structure and function of social systems. Social change occurs in 3 (three) stages, namely: (1) Invention, (2) Diffusion, and (3) Consequences. Invention is a process in which new ideas are created or developed. Diffusion is a process in which new ideas are communicated to members of the social system, while the consequence is a change in the social system as a result of the adoption or rejection of innovation.

Often, innovation is closely related to an environment that is characterized by dynamic and developing. The notion of innovation itself is very diverse, and from many perspectives. ${ }^{2}$ Rogers explained that innovation is an idea, practice, or object that is considered new by the individual one adoption unit to another. Meanwhile, according to Damanpour, an innovation can be in the form of a new product or service, a new product process technology, a new structural and administrative system or a new plan for members of the organization. ${ }^{3}$

Normatively, the central government guarantees protection to regional heads that doing discretion to accelerate development and community welfare through regional innovation. Act No. 23 of 2014 concerning Local Government, and Act No. 30 of 2014 concerning Government Administration, which guarantees discretion by regional heads. In principle, this can be a guideline for regional heads to innovate and do discretion without hesitation and fear.

This action can be said as a reflection of the value of justice. Discretion because legal authority is a moral decision in realizing and placing justice in a proportionate manner, so that justice can be realized in the context of people' lives. This assumption can be referred to John Rawls's view of "moral decisions". 4 Thus, based on Rawls's theory of moral decisions, it can be said theoretically that the discretion of State officials based on innovative policy principles can be justified ideally because this decision is the result of rational-moral judgment from a State official who exercises their discretionary authority.

\section{Regional Innovation Discretion Practices: Aspects of Legality, Institutionalization, and Seeking Ideal Model}

Discretionary policies in the context of realizing regional innovation become urgent in the context of social changes. ${ }^{5}$ After the shift in power that was centralistic in the era of the New Order government, the reform era provided significant opportunities, especially for local governments in autonomy to independently manage their regional affairs. Now, innovative policies are more likely to be exercised, compared to the previous era. Therefore, discretionary policies also have the same opportunity to be constructively implemented especially in specific conditions, where a situation that requires handling outside the existing channels of legality. The only problem is that one of them is the inability of the bureaucracy to do accretion professionally, such as the low quality of public services due to the low professionalism of the bureaucracy.

The low quality of public services is partly due to the low professionalism of the bureaucracy so that the bureaucracy is not able to utilize the space of discretion that should be used in order to increase responsiveness to the demands of society. Local government bureaucratic discretion as a safety valve for policy gaps (especially those determined by the center) with the real needs of people in more dynamic regions, has not been used properly. There are still many policies and regulations that are implemented in the regions that are apparently not appropriate

\footnotetext{
${ }^{1}$ Suhendra, A. (2018). Inovasi Daerah dalam Reformasi Pemerintahan Kota Tangerang Selatan dan Magelang, Jurnal Mitra Pembaharuan, 2 (1): 43

${ }^{2}$ Suwarno, Y. (2008). Inovasi di Sektor Publik. STIA-LAN Press, Jakarta, p. 25

${ }^{3}$ Rogers, E.M. (1961). Diffusion of Innovations. London: The Free Press, p. 4

${ }^{4}$ Fattah, D. (2013). Teori Keadilan Menurut John Rawls, Jurnal TAPIs, 9(2): 32.

${ }^{5}$ Xiao-ying, L.I.N. (2007). Rules and Administrative Discretion in Educational Policy-Making: With Special Reference to two Nongovernmental Higher Education Policies. Tsinghua Journal of Education, 4(2): 131-46.
} 
and do not answer the people's real needs. The cause of discrepancy was not only because the policy was more determined by the central government, but also because local government administration officials had not been able to fully implement the vision and commitment for the people's welfare. ${ }^{1}$

In effort to implement regional innovation discretionary policies, special attention and apprenticeships are needed by both the central and local government itself, so that this discretion policy can be one of the drivers of increasing regional welfare. It is necessary to empower the power of the bureaucracy, because the great power of the bureaucracy without proper empowerment will also weaken the overall potential power of the bureaucracy itself.

In terms of juridical or regulatory aspects, the central government has provided a guarantee of protection to regional heads that do discretionary measures in the context of accelerating development for the people's welfare through regional innovation. Therefore, the practice of discretion in the national government system has been legally made possible by a variety of regulations or legal policies, so that this can be interpreted that discretion is an act of public officials who have a legal basis. This legality shows ideally the discretion by a public official in the regional administration, especially in the context of developing an innovation in the region, substantially constituting an action within the legality framework of a constitutional State. According to the principle of legality, a government can only take legal actions if it has legality or it is based on a law which is a manifestation of the aspirations of citizens.

One of the innovative policies by the government of Gowa regency, South Sulawesi province in the field of the education system is a Policy of Sustainable Completed Class System. Since 2013, the government of Gowa regency has made an innovative policy, which was implemented above the regional regulation of Gowa regency No. 10 of 2013 concerning Sustainable Completed Classes. During the era of the leadership of Gowa Regent Ichsan Yasin Limpo, the government issued a policy on Sustainable Completed Class System (SKTB - Sistem Kelas Tuntas Berkelanjutan). This system has been socialized since 2011 and later in 2013 it will be carried out thoroughly in all levels of education in Gowa regency, from elementary, junior, high and vocational school.

The Sustainable Completed Class System, hereinafter abbreviated as SKTB, is a policy of the government of Gowa regency in education program that seeks to provide optimal educational services to students through a strategy of completing all competency standard and basic competencies in each subject in a sustainable manner. ${ }^{2}$ This innovative policy by the government of Gowa regency since 2013 is a breakthrough made by local government officials regarding the real conditions faced by their citizens in the field of education system development. This policy then became a kind of pilot project and several other local governments then made other related innovative policies.

Aside from South Sulawesi province related to innovative policies, Tegal city, Central Java province, there are also innovative policy practices that are conducted discretely, especially in the field of public health services. The innovative policy was named by the government of Tegal as Jaminan Kesehatan Masyarakat Semesta. This discretionary policy is implemented to provide quality and fair health services, especially in financing for residents who have not received health insurance coverage.

Based on two samples of the implementation of innovative policy discretion both by the government of Gowa regency and Tegal, it can be emphasized that the implementation of the discretionary as conducted is a path of legality, so that legally the actions of the local government are still actions within the framework of the constitutional State system because the policy is based on regulation of existing legal systems. Comparatively, the two policies each have a strong legal basis.

From another aspect, institutional capacity is one of the main issues in the implementation of innovative policies in local government which is carried out discretely. This institutional capacity has been a problem throughout the history of community development carried out by the government since the early independence period until the current reform period. Admittedly, because the position of our country as a developing country and ready to advance, the problem of the capacity of government bureaucratic organizations become a fundamental problem faced by this country in its development process. Especially if it is associated with the phenomenon of the current reform era, where various development efforts are carried out, especially those related to the development of local government innovation policies.

There are various problems found in the development of local government innovation, for example, as what was conveyed by Fadel $\mathrm{M},{ }^{3}$ that the problem of local government innovation can be seen in the perspective of reinventing local government. In this perspective, the problem of local government innovation development is intertwined in several areas that need serious attention including: the problem of leadership. Leadership must be a driver of change. A leader who has a clear vision will encourage his followers to realize that vision through his creative and innovative power. Leaders who have a vision are certainly not enough but political will is also needed,

\footnotetext{
${ }^{1}$ Warsito and Yuwono, T. (2003). Otonomi Daerah: Capacity Building dan Penguatan Demokrasi Lokal, Puskodak-UNDIP, Semarang, p.81.

${ }^{2}$ Local Regulation of Gowa Regency No.10 of 2013 concerning the Sistem Kelas Tuntas Berkelanjutan (SKTB).

${ }^{3}$ Fadel, M. (2009). Reinventing Local Government: Pengalaman dari Daerah. Jakarta: Gramedia. p.396
} 
because leadership in the public sector is political. Without a strong political will from the leadership of the local government it is almost impossible for an innovation to succeed.

Then, related with organizational culture. Most public organizations today are still oriented towards group and hierarchical culture, this cultural orientation tends to inhibit innovation. ${ }^{1}$ And, related to the issue of incentives and rewards. Employees must be given space to conduct experiments and find new solutions to meet the demands and problems faced by the communities. Successful experiments must be given incentives and rewards so that they are motivated to continue to innovate. Then, the problem of innovation capacity, both individual capacity and system capacity. Capacity at the individual and organizational level is important and become a key to how the organization and the people in it manage creative input in the innovation process. ${ }^{2}$

This paper show that there are at least 3 (three) main points in relation to institutional capacity issues in the context of improving the performance of the implementation of local government, for an innovative policy effort, it can be done, the first is regulative systems, there must be regulatory certainty in its implementation, the second is normative systems, as values needed for both leaders and implementer of technical services so that innovation goals can be achieved, and the third is cultural-cognitive systems, organizational culture is creating good habits of people in the organization to support the realization of innovative policy goals. Thus, it can actually manifest what is referred to as good governance, where this innovative policy reflects good governance.

Factor of this leadership can be said to be the influence of political-power factors in the ideal sense. A politic is really just a way for the authorities to realize ideal human values or expectations, how to help citizens to realize their ideal future. The dominant leadership factor in the institutional capacity that embodies the innovative policies of the two local governments can be said in line with the conception of governance introduced by the State Administration Agency.

The State Administration Agency $^{3}$ provides the understanding of governance as the process of implementing the authority of the State in conducting the provision of public goods and services (the need for public goods and services). Thus, the term governance does not only mean a way or method, action, activity, or system, but also means the way of power/authority is used, the use of economic, political and administrative authority/instruments as instruments of public policy and the process of social political interaction. In other words, governance is a process by which State institutions, business entities and community groups express their interests, exercise their rights and obligations, and mediate their differences. Also, governance is not something the State (government) does to its citizens, but the way of community and the individuals within it regulate all aspects of shared-life.

The end, the author comes to the conclusion that the ideal concept of implementing discretionary policies in Indonesia must primarily rest on the main value base as a welfare state. The concept of welfare state is a key concept in one of the objectives of administering the government through public services administratively. Public services can be interpreted as certain activities and objects specifically intended to meet the needs of the general public or provide support for efforts to increase comfort and pleasure for the entire community. In Indonesian administrative law, the term "public service" is defined as "all service activities carried out by government agencies as an effort to meet the needs of people, the public, government agencies and legal entities as well as the implementation of statutory provisions.

Also, another key element that is urgent at an implementing level in this ideal model is the existence of an integrated and directed discretionary policy implementation in a collaboration between the authorities and/or competent in implementing this discretion policy organically or institutionally. Collaboration is needed at every level of the organization, because in essence collaboration is cooperation. Collaboration can take place in two contexts, namely internal organization and external organizational or inter-organizational conducted by several organizations (two or more) in order to achieve certain goals. ${ }^{4}$

In the context of this collaboration, the implementation of discretion must be able to identify the implementing agency, so that it can provide a professional guarantee of the realization of the vision and mission of the policy in this secretion. The readiness of human resources and the expertise required deserves a major consideration in this integrated collaboration system, because it is implemented as a guarantee of the successful implementation of this discretion policy at the technical level. This element can be considered institutionally because it involves the technical ability of the institution in implementing a discrete policy (Figure 2).

This integrated collaboration element is included as one of the important elements in an ideal model of the implementation of discretion for innovation policies in region, based on the consideration that the evaluation of an innovative policy and can be used as best practice is the element of cooperation between related sectors, not only internally but broad scale, namely social environment. Therefore, the concept of collaboration or cooperation as conducted in an integrated manner can be a basic complement in this ideal model. Also, given that often the lack

\footnotetext{
${ }^{1}$ Prasojo, E. (2006). Reformasi Birokrasi di Indonesia: Beberapa Catatan Kritis, Jurnal Bisnis \& Birokrasi, 14 (1): 14.

${ }^{2}$ Fadel M, Op.Cit. p. 340

${ }^{3}$ Lembaga Administrasi Negara. (2008), Manajemen Pemerintahan Daerah, LAN RI, Jakarta.

${ }^{4}$ Utami, S. B., \& Pancasilawan, R. (2017). Kolaborasi dalam Pengelolaan Kawasan Konservasi Taman Buru Gunung Masigit Kareumbi Provinsi Jawa Barat. Jurnal Manajemen Pelayanan Publik, 1(1), 59-73.
} 
of collaboration between parties, an innovative policy becomes ineffective because the implementation process does not take into account the concept of cooperation or collaboration, so that the policy seems to run on the spot, without maximum achievement.

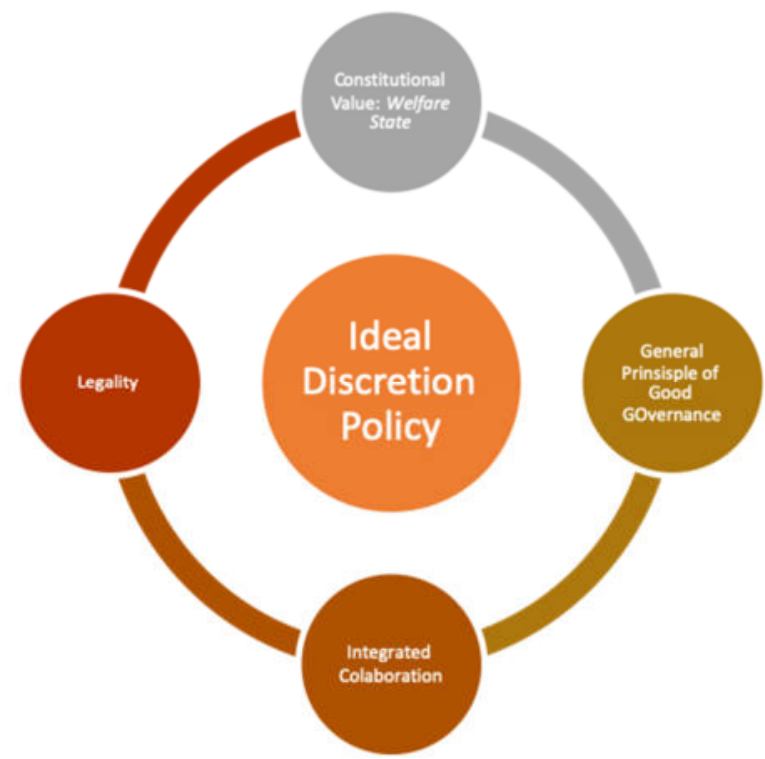

Figure 2. An ideal model of discretion in making innovation policies in region

Conceptually, an ideal model of discretionary policy for innovation programs in local government can be said as a description of the basic system of implementing discretion for policies that are innovative, where the legal actions taken by local governments are based on an ideal principle, so that the guarantee in the discretionary decision is not contrary to all moral or wisdom, moral, ethical, judicial and professional elements.

This model is not structural or hierarchical in nature, but is a unified whole with each basic element having the same strengths and interests, so that all elements are bound together with strengths and positions, both from elements of the constitutional value, welfare state, legality, general principle of good governance and integrated collaboration. The four of basic elements creates an ideal model of discretion, in response to the dilemmatic attitude that is often absent in the public administration field of the State government when an official implement or takes discretionary decisions that lead to the achievement of constitutional values, that Indonesia as a consequent welfare state.

\section{Conclusions}

The essence of discretionary power is free-power that no longer exercised by following the consideration of rules and regulations. Discretionary power holders in acting do not need to underlie the law strictly because it is an exception then discretionary power can only be used casually or contextually. Discretionary power as an act of the State is lawful, linear or in line with the concept of the constitutional State. Essentially, discretion reflects the idea of the constitutional State, then the action of discretion by State officials in the framework of innovative policy efforts is actually a moral manifestation of State' responsibility.

Conceptually, an ideal model of discretionary policy for innovation programs in local government can be said as a description of the basic system of implementing discretion for policies that are innovative, where the legal actions taken by local governments are based on an ideal principle, so that it become guarantee in the discretionary decision and not contrary to all moral or wisdom, moral, ethical, judicial and professional elements. This model is not structural or hierarchical in nature, but a unified whole with each basic element having the same strengths and interests, so that all elements are bound together with strengths and positions, both from elements of the constitutional value, welfare state, legality, general principle of good governance and integrated collaboration.

\section{References}

Ansori, L. (2015). Diskresi dan Pertanggungjawaban Pemerintah Dalam Penyelenggaraan Pemerintahan. Journal of Juridical 2 (1): 137.

Aristoni, (2014), Tindakan Hukum Diskresi Dalam Konsep Walfare State Perspektif Hukum Administrasi Negara dan Hukum Islam, Jurnal Penelitian STAIN Kudus, 8 (2): 224.

Aspan, Z., \& Yunus, A. (2019). The right to a good and healthy environment: Revitalizing green constitution. IOP Conference Series: Earth and Environmental Science, 343 (1): 012067.

BeritaSatu.com. Available online at: https://www.beritasatu.com/nasional/133220/ma-vonis-mantan- bupati- 
jembrana accessed on 1 November 2019

Fadel, M. (2009). Reinventing Local Government: Pengalaman dari Daerah. Jakarta: Gramedia.

Fattah, D. (2013). Teori Keadilan Menurut John Rawls, Jurnal TAPIs, 9(2): 32.

Fendri, A. (2015). Kebebasan bertindak pemerintah (diskresi)sebagai perwujudan nilai-nilai moral dan etika. The Journal of Law Science, 4 (3): 138.

Hadjon, P. M. (2011). Introduction to the Indonesian administrative law. Yogyakarta: Gadjah Mada University Press.

Hadjon, P.M. Discretionary Power dan Asas-Asas Umum Pemerintahan Yang Baik. Paper on the National Seminar “Aspek Pertanggungjawaban Pidana Dalam Kebijakan Publik dari Tindak Pidana Korupsi”, Semarang, 6-7 May 2004

Ilmar, A. (2014). Hukum Tata Pemerintahan. Prenadamedia. Jakarta.

Kompasiana.com. Available online at: http://www.kompasiana.com/hendra budiman/landasan- hukum-inovasikota-cerdas accessed on 1 November 2019

Lembaga Administrasi Negara. (2008), Manajemen Pemerintahan Daerah, LAN RI, Jakarta.

Local Regulation of Gowa Regency No.10 of 2013 concerning the Sistem Kelas Tuntas Berkelanjutan.

Marzuki, P.M. (2010). Penelitian Hukum. Jakarta: Kencana Prenada Media Group.

Merdeka.com Available online at: https:/www.merdeka.com/peristiwa/ma-vonis-mantan-bupati- sragen-7-tahunpenjara.html accessed on 1 November 2019

Patton, M.Q., and Cochran, M. (2007). A Guide to Using Qualitative Research Methodology, Medecins Sans Frontieres, UK.

Prasojo, E. (2006). Reformasi Birokrasi di Indonesia: Beberapa Catatan Kritis, Jurnal Bisnis \& Birokrasi, 14 (1): 14.

Razak, A. (2005). Kedudukan dan Fungsi Peraturan Kebijakan di Bidang Perizinan dalam Rangka Penyelenggaraan Pemerintahan. (Dissertation). Post-graduate, Hasanuddin University.

Rogers, E.M. (1961). Diffusion of Innovations. London: The Free Press.

Suhendra, A. (2018). Inovasi Daerah dalam Reformasi Pemerintahan Kota Tangerang Selatan dan Magelang, Jurnal Mitra Pembaharuan, 2 (1): 43

Sururi, A. (2017). Inovasi Kebijakan dalam Perspektif Administrasi Publik Menuju Terwujudnya Good Public Policy Governance, Jurnal Spirit Publik, 12 (2): 14-31.

Suwarno, Y. (2008). Inovasi di Sektor Publik. STIA-LAN Press, Jakarta.

Utami, S. B., \& Pancasilawan, R. (2017). Kolaborasi dalam Pengelolaan Kawasan Konservasi Taman Buru Gunung Masigit Kareumbi Provinsi Jawa Barat. Jurnal Manajemen Pelayanan Publik, 1(1), 59-73.

Vega, A., Chiasson, M., \& Brown, D. (2013). Understanding the Causes of Informal and Formal Discretion in the Delivery of Enterprise Policies: A Multiple Case Study. Environment and Planning C: Government and Policy, 31(1), 102-118. https://doi.org/10.1068/c1101b

Warsito and Yuwono, T. (2003). Otonomi Daerah: Capacity Building dan Penguatan Demokrasi Lokal, PuskodakUNDIP, Semarang.

Wilson, J., \& Stapleton, K. (2007). The discourse of resistance: Social change and policing in Northern Ireland. Language in Society, 36(3), 393-425. doi:10.1017/S0047404507070194.

Xiao-ying, L.I.N. (2007). Rules and Administrative Discretion in Educational Policy-Making: With Special Reference to two Non-governmental Higher Education Policies. Tsinghua Journal of Education, 4(2): 13146. 